which forbade any foreigner to go in under pain of death."-Ant. xv. xi. 5 .

But this passage from the "Antiquities" will lend fresh support to $M$. Ganneau in his previous statement: "Les rapports sont frappants entre ce texte et notre inscription; les expressions mêmes et les formes sont

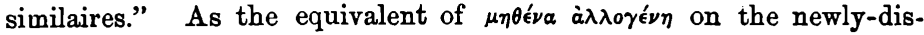
covered stone, he may now quote $\tau \partial \nu$ à $\lambda \lambda o \in \theta \nu \hat{\eta}$ from the "Antiquities," as well as $\mu \eta \delta \hat{\epsilon} \iota \nu$ a $a \lambda \delta \phi \nu \lambda o \nu$ from the "Wars;" and while the stone says $\tau \hat{o} v$

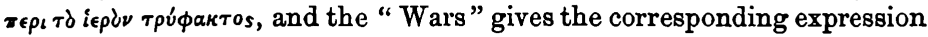

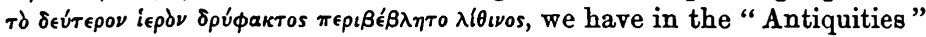

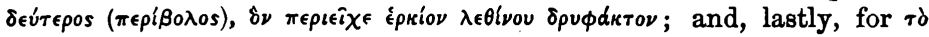

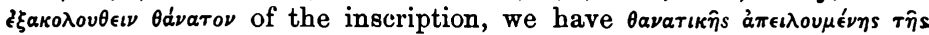
Snuias in the "Antiquities." But the chief use of this parallel passage from the " Antiquities " is to show that, since it is differently worded from the passage in the "Wars," Josephus had no intention of giving us. the exact phraseology of the inscription, but only the sense; and therefore, that the stele should give the sense of Josephus without his exact words is just what was to be looked for in such a discovery.

George St. Clair.

\title{
INSCRIPTIONS DISCOVERED AT HAMATH IN NORTHERN SYRIA.*
}

\section{BY J. AUGUSTUS JOHNSON, LATE U. S. CONSUL-GENERAL AT BEYROUT.}

THE discovery of the "Moabite Stone" has stimulated the curiosity. of Orientalists and Bible readers, and has naturally called the attention of explorer's to the districts east of the Jordan. But there is another district, too long overlooked, which, it is believed, will repay a careful. examination.

Hamath, on the northern border of the "Promised Land," was the capital of a kingdom at the Exodus; its king, Toi, yielded allegiance ta King David (2 Sam. viii. 9); it was called "great" by Amos (vi. 2), and was spoken of by an Assyrian monarch as among the most celebrated of his conquests ( $2 \mathrm{Kings}$ xviii. 34). It was originally the residence of Canaanites (Gen. x. 18), and is frequently mentioned as the extreme limit of the Holy Land towards the north. Hamath, as it is now called, has at present a population of about 30,000 inhabitants.

While looking through the bazaar of this old town, in 1870, with the Rev. S. Jessup, of the Syria Mission, we came upon a stone in the corner of a house which contained an inscription in unknown characters. We did not succeed in getting squeeze-impressions, for fanatical

* From Quarterly Statement, No. 1, of the American Exploration Society. 
Moslems crowded upon us when we began to work upon the stone and we were obliged to be content with such copies of this and other inscriptions subsequently found on stones over and near the city gate, and in the ancient bridge which spans the Orontes, as could be obtained by the aid of a native painter. In this we were greatly aided by $\mathrm{Mr}$. Jessup, and by Mr. F. Bambino, of the French Consulate, who pronounced the copies to be accurate. Mr. Jessup endeavoured to purchase a blue stone containing two lines of these strange characters, but failed to obtain it because of the tradition connected with, and the income derived from it. Deformed persons were willing to pay for the privilege of lying upon it in the hope of a speedy cure, as it was believed to be efficacious in spinal diseases.

We should naturally expect to find in this vicinity some trace of the Assyrian and Egyptian conquerors who have ravaged the valley of the Orontes, and of their struggles with the Hittites on this ancient battlefield, and of Solomon, who built stone cities in Hamath ( 2 Chron. viii. 4), of which Palmyra was one. But we find nothing of the Palmyrene on these stones. The arrow-headed characters are suggestive of Assournasirpal. In the inscription on the monolith of Nimroud, preserved in the British Museum, in relating bis exploits 915 B.c., he says : "In this time I took the environs of Mt. Lebanon. I went towards the great sea of Phœnicia. . . . I received tributes from . . . Tyre, Sidon, \&c. . . . They humbled themselves before me." And a little later, 879-8 B.c., Salmanazar V. says: "In my twenty-first campaign I crossed the Euphrates for the twenty-first time; I marched towards the cities of Hazael, of Damascus. I received the tributes of Tyre, Sidon, and Gebal."

Until the interpretation of these mysterious characters shall be given, a wide field is open to conjecture. Alphabetic writing was in use 1500 B.c., but the germs of the alphabetic system were found in the hieroglyphic and hieratic writing of the Egyptians, upwards of 2000 B.c. Some of the attempts at picture-writing on these Hamath stones suggest the Egyptian system, which consists of a certain number of figures to express letters or syllables, and a vast number of ideographic or symbolic forms to represent words. Other characters represent Phœnician letters and numerals not unlike the Phœnician writing on the foundation stones of the Temple at Jerusalem, recently deciphered by M. Deutsch, of the British Museum.

In framing their alphabet the Phœnicians adopted the same process previously employed in the Egyptian phonetic system, by taking the first letter of the name of the object chosen to represent each sound; as, A, for aleph (a bull); B, for beth (a house); G, for ghimel (a camel); in the same manner as the Egyptians represented $A$, by an eagle, akhem; $\mathrm{M}$, by an owl, moulag, \&c.

Some scholars have designated Babylonia as the true mother of the characters employed in very ancient times in Syria and Mesopotamia. And it appears that besides the cuneiform writing found on Assyrian 
and Babylonian monuments, a cursive character was also employed, identical with the Phœnician, and therefore possibly borrowed by the latter. Kenrick, however, remarks on this theory, that the occurrence of these characters only proves the intercourse between the two people, and not that the cuneiform was the parent of the Phœnician. We have in these inscriptions of Hamath a melange of all three, and perhaps a connecting link between the carliest systems. To suppose them to be bi-lingual or tri-lingual only increases the difficulty of interpretation in this case, for there is not enough of either to furnish a clue to the rest.

The "Carpentras Stone" contains an analogous inscription; it comes near to the Phonician, and has been thought to present the most ancient specimen of the Aramean series. This and the Palmyrene writing form the links between the coin characters and the square characters, and are supposed to represent a language in a state of transition. That the Hebrews borrowed the use of writing from Mesopotamia or Phœnicia has been universally admitted; and, according to Gesenius, the old form of their writing was derived from the Phœnician, and retained by the Samaritans after the Jews had adopted another character of Aramaic origin.

Now may it not be that in these Hamath inscriptions we have fallen upon a transition period, when the Phœnicians, or their predecessors in the land, were using the elements of writing then in existence, and before the regular and simple Phœnician alphabet had been perfected?

The "Carpentras Stone" has been considered by Gesenius to have been executed by a Syrian of the Seleucidian period. The "Rosetti Stone" dates back to 193 B.c. The characters on these stones have much in common with those of Hamath. "Champollion's Key to the Hieroglyphics" will be of aid perhaps in solving the present mystery. But we shall be surprised if the inscriptions of Hamath do not prove to be older and of greater interest than any recent discovery of EgyptoAramean or hieroglyphic characters.

Mr. E. H. Palmer saw our copies at Beyrout, while on his way from an exploring tour in the Desert of Tîh. He was so persuaded of their archæological importance, that he induced the British Society to send Mr. Tyrwhitt Drake to Syria, to obtain squeeze-impressions and photographs of all these and any other similar inscriptions. His report will be looked for with great interest. In the last number of the Journal of the American Oriental Society, it is stated that Mr. Palmer has already found in a Syrian MS. lying in the University of Cambridge, other copies of these Hamath inscriptions. They are said to be imperfect. We do not learn, however, that the Syrian MS. has been translated, or that any theory of interpretation has been advanced. Dr. Eisenlohr, Professor of Egyptology at the University of Heidelberg, in a letter asking permission to publish these inscriptions in Germany, says: "Though I believe we are at present not able to give a translation of these inscriptions, I am still persuaded they will be of the highest interest for the scientific world, because they are a specinen of the first manner of writing of the people of that country." 
These inscriptions, and the bas-reliefs on the monument called Kamua Hurmul, in Cœlo-Syria, near the source of the Orontes, and possibly of the same period, are an enigma, as yet, to the most learned Orientalists. It is to be hoped, however, now that attention is again called to the subject, that the clue may be found that shall unlock their. meaning, and that Northern Syria will be no longer overlooked by the explorer.

\section{DISCOVERY AT THE MOSQUE EL AKSA, JERUSALEM.*}

A DIscovery of considerable interest has been made in this Mosque by the Rev. J. Neil, who has only recently gone to Jerusalem for the Society for the Conversion of the Jews. "In the Mosque of El Aksa," he writes, "you will remember that there is a long plain roon opening out at the south-east angle, called the Mosque of Omar, in which the only object of interest whatever is a recess supported by two twisted pillars, and called the Mibrab, or Praying-place of Omar. You may, perhaps, remember that the pillars on each side of this recess, of Solomonic twisted pattern and polished marble, appear to have been turned upside down, and to have their capitals of greyish stone in broken leaf-like patterns below. On visiting this the day before yesterday, July 5th, I discovered that a great part of the yellowish plaster had been removed from the top of these pillars, and that rich grotesquely carved capitals were exposed to view in an admirable state of preservation. These capitals, though pressing behind against the wall, are carved on all the four sides. The Sheikh of the temple told me this was first seen about two days before my visit, while cleaning the wall. . . The sketches I send are shamefully rough, but I have no idea of drawing : they were made by myself from still rougher sketches."

These drawings are at the office of the Palestine Exploration Fund, 9, Pall Mall East, where they have been sent by the Rev. F. Smith, to whom Mr. Neil was writing.

\section{ON THE RELATIONS OF CANAANITE EXPLORATION TO PRE-HISTORIC CLASSIC ARCHÆOLOGY.}

BY IIYDE CLARKE.

Iv a late paper in the Journal of the Palestine Exploration Fund, I showed, on the evidence of the river names of Palestine, what was the connection of the Canaanite pupulation with general history, and I called the attention of investigators to the probability of discovering pre-Israelite monuments and relics. As an effort is now being made

* Reprinted, by kind permission of the editor, from the Athencellm. 